\title{
Prunus armeniaca effects on expression of genes related to apoptosis in human breast cancer cells
}

\author{
Esmaeil Mahmoudi ${ }^{1}$, Mahdieh Abolfathi ${ }^{2}$, Naiemeh Hassanzadeh ${ }^{3}$, Yaser Eshaghi Milasi ${ }^{4}$, Mina Dehghani-Samani ${ }^{5}$,

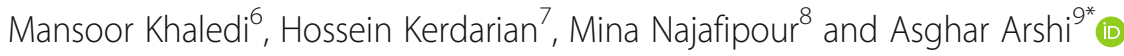

\begin{abstract}
Background: Apoptosis inhibition depends on the balance between expression of some regulatory genes including Bax and c-FLIP, despite breast cancer has long been associated with disturbances in apoptosis regulation. The objective of present study was to determine the expression levels of Bax and c-FLIP mRNAs in $1 \mu \mathrm{g}$ sample of total RNA obtained from MCF7 and MDA-MB-231 human breast cancer cells treated with Prunus armeniaca extract.

Methods: Prunus armeniaca effect was measured by MTT assay with different drug concentrations $(0.5,1,1.5,2,2.5$, $3,3.5,4,4.5$ and $5 \mathrm{mg} / \mathrm{mL}$ ) at different incubation times (24, 48 and $72 \mathrm{~h}$ ). Expression of Bax and c-FLIP mRNA levels was determined by qRT-PCR technique.

Results: The results of this study indicated that Prunus armeniaca significantly inhibited proliferation of cells in concentration-dependent manner in all the time of incubation $(P<0.05)$. Our findings also showed that the expression level of Bax and c-FLIP genes were increased in untreat group compared with control group in both of cancer cells at all the time $(P<0.001)$. Prunus armeniaca reduced the expression level of Bax and $c-F L I P$ genes cancer cells as a timedependence manner with respect to the untreat group significantly $(P<0.001)$.

Conclusion: The expression level of Bax and C-FLIP genes were significantly decreased under treatment of Prunus armeniaca extract and it may be helpful in the prevention and cure of breast cancer in usage of herbal remedies.
\end{abstract}

Keywords: Breast cancer cells, Prunus armeniaca, Bax, C-FLIP

\section{Background}

Today breast cancer, that is the most common malignity, is a significant challenge to human health which causes death females all over the world. In 2018, out of $1,735,350$ cancers in the United States, 266,120 cases are related to breast cancer. The estimated death rate for breast cancer was 40,920 which unfortunately has a high proportion of cancers [1]. Apoptosis is a series of cellular events in which organisms have evolved to destroying cells which are not necessary or unhealthy cells from the body during development or cellular stress. Expression of the Bax (Bcl-2-associated X) and c-FLIP (Cellular FLICE-inhibitory protein) genes results in the promotion

\footnotetext{
* Correspondence: asghararshi@iaushk.ac.ir

${ }^{9}$ Young Researchers and Elite Club, Najafabad Branch, Islamic Azad University, Najafabad, Iran

Full list of author information is available at the end of the article
}

of cell survival by inhibiting apoptosis. Therefore, a novel approach to suppress anti-apoptotic genes is using of apricot (Prunus armeniaca L.) in cancer cells [2, 3]. c-FLIP gene, is an important component of the death-inducing signaling complex (DISC), antioxidant, structurally similar to caspase- 8 and contains two death effector domains (short (c-FLIPS) and long (c-FLIPL) based on their size) and a caspase-like domain $[4,5]$. The expression of $c$-FLIP in breast cancer is associated with chemotherapy and tumor necrosis factor-related apoptosis-inducing ligand (TRAIL) resistance and is overexpressed in many types of human tumor compared with matched normal tissue, suggesting that $c$-FLIP may contribute to tumorigenesis in vivo [6]. Bax gene, plays the key role in apoptosis pathway and is the gateway to the mitochondrial pathway of apoptosis. It has been suggested that the Bax determine cell fate, survival or death, when exposed to apoptotic stimuli 
such as removal of the growth factor $[7,8]$. The $\operatorname{Bax}$ gene encodes several variants of $\operatorname{Bax}$ (principal form is $\operatorname{Bax} \alpha$ ) and can produce different proteins through alternative mRNA splicing mechanisms (such as $\alpha, \beta, \gamma$, and $\delta$ isoforms of $B a x$ ) [9]. Apricot has been used in folk medicine as a remedy for various diseases and contains amygdalin, carbohydrates, vitamins $\mathrm{C}$ and $\mathrm{K}, \beta$-carotene, niacin, thiamine, dietary protein and along with significant amounts of oil and fiber [10, 11]. Antioxidant and anti-cancer activities of Prunus armeniaca extract have been poorly studied, and the lack of studies stimulated the present research. Mounting evidence has supported the anti-cancer effects of Prunus armeniaca extract in cancer cure. However, whether Prunus armeniaca indeed acts as an anti-tumor agent against breast cancer cells is not clear. Based on the above, we investigate the changes in mRNA expression profiles of Bax and c-FLIP genes after treatment of MCF7 and MDA-MB-231 cells with Prunus armeniaca extract.

\section{Material and methods Cell culture}

The MCF7 (ATCC ${ }^{ø}$ HTB22 $^{\text {тм }}$ ), MDA-MB-231 (ATCC ${ }^{ø}$ HTB-26 $^{\mathrm{Tm}}$ ) and HDF (ATCC ${ }^{\oplus}$ PCS-201-010 ${ }^{\mathrm{Tn}}$ ) were obtained from Pasteur Institute (Tehran, Iran). Cells were maintained in RPMI medium 1640 (Gibco Invitrogen) containing $10 \%$ fetal bovine serum (FBS) (Gibco-Invitrogen), $2 \mathrm{~g} / \mathrm{L}$ sodium bicarbonate and $1 \%$ penicillin/ streptomycin (Gibco-Invitrogen). Cells were grown in a humidified Incubator at $37^{\circ} \mathrm{C}$, in a $95 \%$ air- $5 \% \mathrm{CO}_{2}$ atmosphere. When the cells reached $80 \%$ confluences and sub-cultured they were harvested with $0.5 \mathrm{~g} / \mathrm{l}$ trypsin (Gibco Laboratories) and $0.2 \mathrm{~g} / \mathrm{l}$ EDTA (Gibco Laboratories) for $4 \mathrm{~min}$ for further passages. In all experiments, cells were seeded and then incubated $24 \mathrm{~h}$ before each assay.

\section{Drug preparation}

Prunus armeniaca was obtained from Sigma Aldrich (St. Louis, MO, USA) and the stock solution was made at concentrations of $1000 \mu \mathrm{g} / \mathrm{ml}$. Stock solution was filtered the final treating concentrations were obtained using diluting in suitable culture medium.

\section{MTT assay}

Cell viability was defined by 3-(4,5-dimethylthiazo1-2-yl)-2,5- dimethyltetrazolium bromide (MTT) assay. Almost 5000 cells/well were plated in 96-well culture dish to determine the effect of Prunus armeniaca on mentioned human cancer cells. After $24 \mathrm{~h}$ incubation the cells were treated with different concentrations of Prunus armeniaca, i.e. 0.5, 1, 1.5, 2, 2.5, 3, 3.5, 4, 4.5 and $5 \mathrm{mg} / \mathrm{mL}$ for 24,48 and $72 \mathrm{~h}$. After the treatment period, $20 \mu \mathrm{l}$ of MTT of $5 \mathrm{mg} / \mathrm{ml}$ in PBS were added to each well and left for $3-4 \mathrm{~h}$ at $37^{\circ} \mathrm{C}$ within the incubator. Following the incubation, MTT solution was eliminated and $100 \mu \mathrm{l}$ of DMSO added for $20 \mathrm{~min}$ at $37^{\circ} \mathrm{C}$. Absorbance was measured using a multi detection micro plate reader at the working wavelength of $540 \mathrm{~nm}$.

\section{RNA extraction and CDNA synthesis}

Total RNA was extracted from cancer cells using the $\mathrm{RNX}^{\mathrm{TM}}$-Plus solution (SinaClon, Iran) according to the manufacturer's instructions. The purity and concentration of the extracted RNA was determined by Thermo Scientific NanoDrop ${ }^{\text {тм }} 1000$ Spectrophotometer (Thermo Scientific, Germany), and the RNA integrity was confirmed by gel electrophoresis. The RNA extraction step was followed by a DNaseI treatment (EN0521, Fermentas, Germany). $1 \mu \mathrm{g}$ of RNA was then used for cDNA synthesis using random hexamers as primers and Prime Script $^{\mathrm{TM}}$-RT kit (TaKaRa, Japan).

\section{Quantitative real time PCR}

Quantitative RT-PCR was carried out using specific primers which shown in Table 1. qRT-PCR performed with $\mathrm{SYBR}^{\circledR}$ Premix Ex $\mathrm{Taq}^{\mathrm{TM}}$ II kit (TaKaRa, Japan) according to the manufacturer's instruction. Rotor gene 6000 Corbett detection system was used for amplification. Thermal cycling condition was set as follows: an initial activation step for $5 \mathrm{~min}$ at $95^{\circ} \mathrm{C}$, followed by 40 cycles of $95^{\circ} \mathrm{C}$ for $15 \mathrm{~s}$ and $60^{\circ} \mathrm{C}$ for $1 \mathrm{~min}$. No template controls (NTC) were also included in each run. The best primer concentrations were identified by performing a series of experiments with varying primer combinations. To verify reaction efficiencies, for each primer set, standard curves were prepared using data from serially diluted samples. Melting curve analyses were also performed for each primer set. Besides, PCR products were electrophoresed on $2 \%$ agarose gel to verify the product sizes. GAPDH housekeeping gene was used as normalizer and HDF cell line was used as the control group for the cancer cell lines. Relative expressions were calculated using $2^{-\Delta \Delta C t}$ method [12]. The qRT-PCR assays were performed in duplicate and the data were presented as the mean \pm standard error of the mean (SEM) where applicable.

Table 1 Sequence of primers for RT-qPCR

\begin{tabular}{llll}
\hline Primers & Primer Sequences (5' to 3') & Ta (C) & Product Size (bp) \\
\hline Bax & TGCCTCAGGATGCGTCCACCAA & 60 & 140 \\
& CCTGTGTCCTGAAGGAGCCCAG & & \\
c-FLIP & GGACTTGGCTGAACTGCTCTAC & 60 & 233 \\
& AACTCTTCTCCTTGCTTATCTTGC & & \\
GAPDH & GAAGGTGAAGGTCGGAGTC & 60 & 226 \\
& GAAGATGGTGATGGGATC & & \\
\hline
\end{tabular}




\section{Statistical analyses}

All the experiments were repeated three times. All the data was analyzed by one way ANOVA test using GraphPad Prism version 7.00 (GraphPad Software, La Jolla California USA). $P$ values $<0.05$ were deemed to be statistically significant.

\section{Results}

Bax and c-FLIP genes expression was studied in MCF7 and MDA-MB-231 breast cancer cells treated with Prunus armeniaca extract.

\section{Prunus armeniaca-induced inhibition of proliferation}

Cytotoxicity effect of prunus armenica was evaluated on three human cells MCF7, MDA-MB-231 and HDF. All cells were treated with different concentration of prunus armenica for incubation time of 24, 48 and $72 \mathrm{~h}$. MTT was used to measure cell viability. As shown in Fig. 1a, Prunus armeniaca decreased growth and proliferation of HDF cells in concentration-dependent manner in all the time of incubation. Prunus armeniaca significantly inhibited proliferation of HDF cells at concentrations (2.5-5), (1.5-5), and $(1-5)$ after 24,48 and $72 \mathrm{~h}$ incubation respectively ( $P$ value $<0.05)$. The cell viability of MCF7 was decreased at concentration of prunus armenica (1-5), (1-5), and (0.5-5) after 24,48 and $72 \mathrm{~h}$ incubation respectively $(P$ value $<$ 0.05) (Fig. 1b). As presented in Fig. 1c, Prunus armeniaca diminished growth and proliferation of MDA-MB-231 cells in concentration-dependent manner in all the time of incubation. Prunus armeniaca significantly inhibited proliferation of MDA-MB-231 cells at concentrations (1-5), (0.5$5)$, and (0.5-5) after 24,48 and $72 \mathrm{~h}$ incubation respectively $(P$ value $<0.05)$. The values of IC50 $(\mu \mathrm{g} / \mathrm{ml})$ were obtained for the cells. As presented in Table 2, the values of IC50 $(\mathrm{mg} / \mathrm{ml})$ were decreased in time of incubation-dependent manner.

\section{Prunus armeniaca effect on Bax and c-FLIP in MCF7 breast cancer cells}

The results of present study indicated that the expression level of Bax and c-FLIP genes were enhanced in untreat group compared with control group in all the time of incubation incubation $(P$ value $<0.001)$ (Fig. 2$)$. As shown as in Fig. 2, Prunus armeniaca significantly inhibited the expression level of Bax and c-FLIP genes versus untreat group in all the time of incubation $(P$ value $<0.001)$. Also our results demonstrated that time will reduce the expression level of Bax gene cancer cells treated by Prunus armeniaca.

\section{Prunus armeniaca effect on Bax and c-FLIP in MDA-MB- 231 breast cancer cells}

As presented in Fig. 3, findings demonstrated a significant enhancement in the expression level of $\mathrm{Bax}$ and

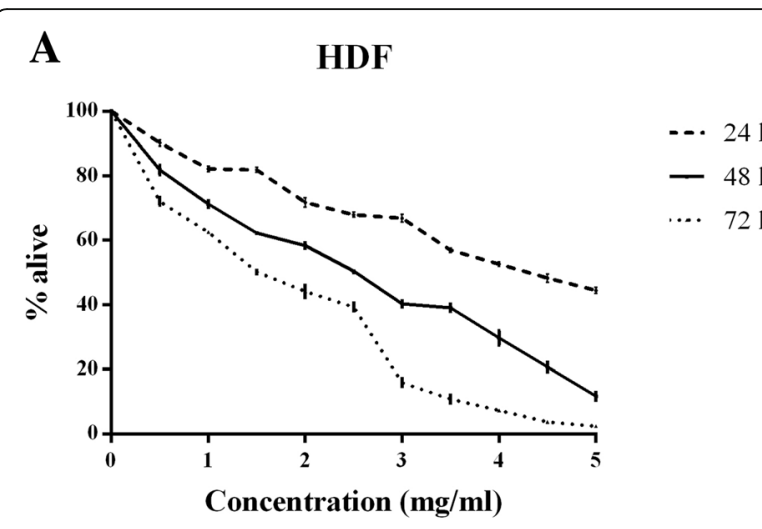

B $\quad \mathrm{MCF} 7$
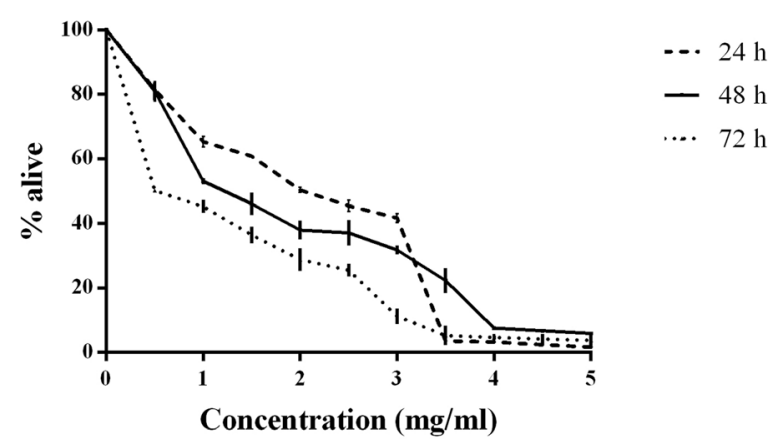

C

MDA-MB-231

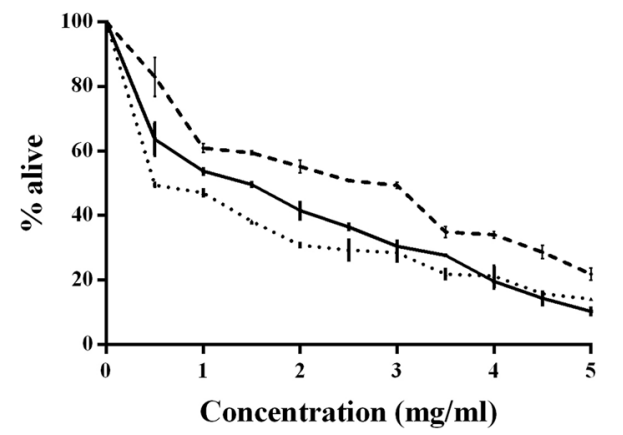

-.. $24 \mathrm{~h}$

- $48 \mathrm{~h}$

… $72 \mathrm{~h}$

Fig. 1 Prunus armeniaca was decreased growth and proliferation of HDF, MCF and MDA-MB-231 cells in concentration-dependent manner in all the time of incubation. a Prunus armeniaca significantly inhibited proliferation at concentrations (2.5-5), (1.5-5), and (1-5) after 24, 48 and $72 \mathrm{~h}$ incubation respectively ( $P$ value $<0.05$ ). b Prunus armeniaca significantly inhibited proliferation at concentrations $(1-5),(1-5)$, and $(0.5-5)$ after 24,48 and $72 \mathrm{~h}$ incubation respectively $(P$ value $<0.05)$. c Prunus armeniaca significantly inhibited proliferation at concentrations $(1-5),(0.5-5)$, and $(0.5-5)$ after 24,48 and $72 \mathrm{~h}$ incubation respectively $(P$ value $<0.05)$

$c$-FLIP genes in untreat group versus with control group at all the time of incubation $(P$ value $<0.001)$. On the other hand, there were a significant reductions in the relative expression levels of Bax and c-FLIP genes after incubation cells with Prunus armeniaca in treat group 
Table 2 IC50 values of HDF, MCF7 and MDA-MB-231 cells lines incubated with prunus armenica for 24,48 and $72 \mathrm{~h}$

\begin{tabular}{llll}
\hline $\mathrm{C}_{50}$ value $(\mathrm{mg} / \mathrm{ml})$ & & & \\
\hline Cell & $24 \mathrm{~h}$ & $48 \mathrm{~h}$ & $72 \mathrm{~h}$ \\
\hline HDF & 4.27 & 2.54 & 1.51 \\
MCF7 & 2.00 & 1.24 & 0.50 \\
MDA-MB-231 & 2.5 & 1.48 & 0.48 \\
\hline
\end{tabular}

compare with untreat group in all three time of incubation $(P$ value $<0.001$ ) (Fig. 3 ). Also Fig. 3, shows that Prunus armeniaca decreased the expression level of these genes in time-dependent manner.

\section{Discussion}

We have established a relationship between the rate of gene expression and Prunus armeniaca extract in human breast cancer cells using quantitative determination of mRNA copy numbers. The Bax and c-FLIP mRNA copy numbers were determined in order to estimate the effects of Prunus armeniaca extract in breast cancer. We observed a correlation between decreased Bax and c-FLIP expression level and Prunus armeniaca extract.

Recently, most cancer research has focused on the deregulation of apoptosis (as a central event) in the beginning of carcinogenesis, further cancer development and a number of studies showed a central role of apoptosis in tumorigenesis of different type of cancer. Different regulators of apoptosis such as p53, Bax, Fas, survivin and c-FLIP have been implicated in the cancer development [13].

$\mathrm{Bcl}-2$ genes have been regulated apoptosis, which promote cell survival and Bax protein. Bax overexpression enhances apoptosis induced by several agents [14]. Hawkins et al. [15] suggested that increased apoptotic frequency is associated with decrease in $\mathrm{Bcl}$-2 expression level. However, lack of $B a x$ protein in human cancers contributes to drug resistance. $\mathrm{Bax}$ is responsible for the mitochondrial apoptosis pathway [16]. In cancer cells, induction of Bax begins cell death [14]. c-FLIP as a novel anti-apoptotic gene, has been revealed to be overexpressed in several human cancers and make c-FLIP an important role in cancer development [17].

Krajewski et al. report demonstrated that low Bax expression in metastatic breast cancer patients had poorer response to chemotherapy and shorter overall survival [18]. They also indicated that there were no differences in treatment outcome related to Bax expression in the tumor cells in breast cancer patients [19].

When we analyzed correlation between $\operatorname{Bax}$ and c-FLIP genes expression under treatment with Prunus armeniaca extract, we found that expression of these gene were lower in treated cells in compared to untreated one. We suspected that Prunus armeniaca extract could be related to inhibition of anti-apoptotic genes in human breast cancer cells.

In the last decade, agents used for cancer treatment are derived from the plant origin, specially flowers, leaves, fruits and fungi. Recent research evidences demonstrated that these plants and herbs play an important role in prevention, cure and keeping human health. Public know herbal remedies as a synthetic medicines because herbals contains natural active compound [20]. Amygdalin, Prunus armeniaca, Ginseng, Garlic and Aloe Vera are some examples of plants which are used in breast cancer treatment [21].

Research on the expression of apoptosis associated genes in different cancer cells treated with herbal remedies showed that the expression of $B c l-2, B c l-X L, B a d$ and $B a x$ genes differed from control cells (un-treated groups) [22]. In agreement with this report, we found that Bax and c-FLIP gene expression levels had a significant decrease in MCF7 and MDA-MB-231 human breast cancer cells undertreated with Prunus armeniaca extract. In a study, mRNA expression level of some anti-apoptotic genes in response to treatment with herbal remedies in breast
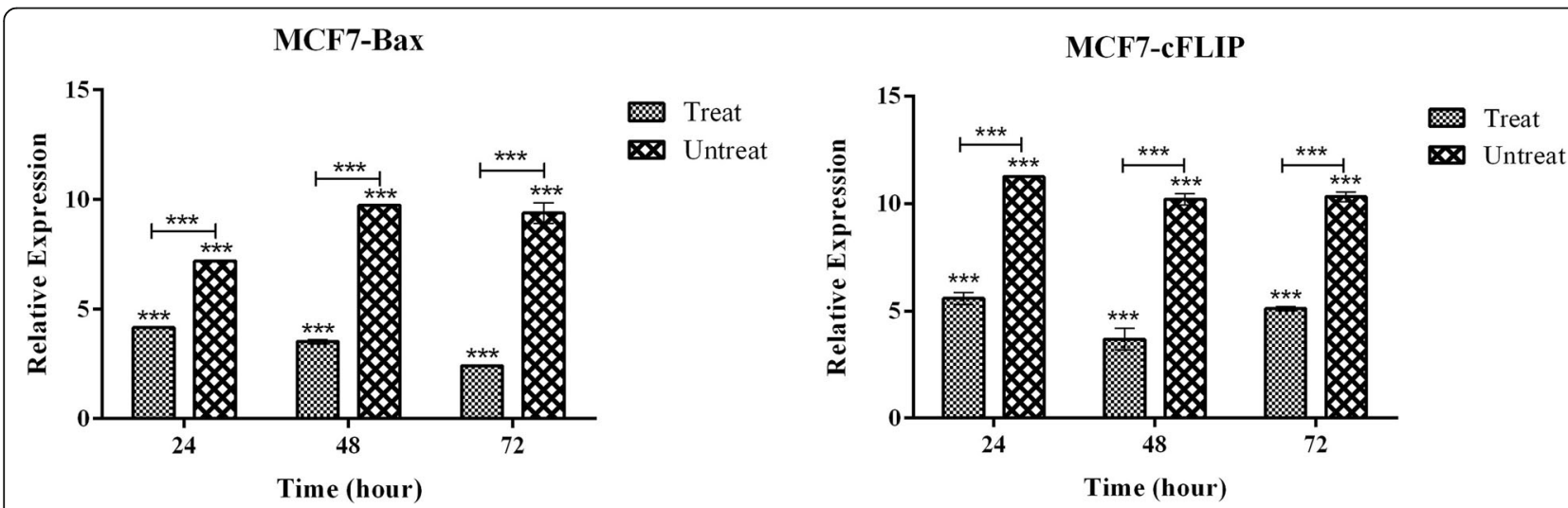

Fig. 2 Relative expression of Bax and C-FLIP in MCF7 breast cancer cells treated by Prunus armeniaca. Expression levels of the genes were evaluated by $\mathrm{qPCR}$ and compared to untreat and control cells by $\triangle \triangle \mathrm{Ct}$ method. ${ }^{* *}$. Shows significant at the 0.001 level. Error bars show $\pm \mathrm{SE}$ 

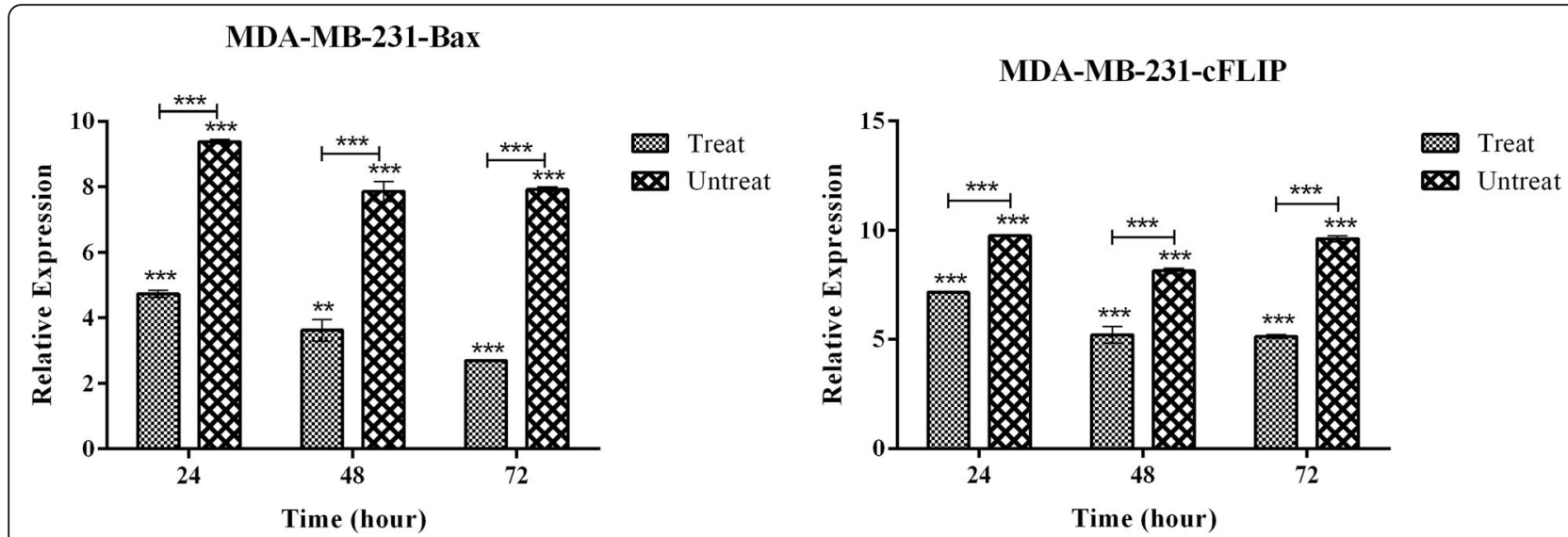

Fig. 3 Relative expression of Bax and c-FLIP in MDA-MB-231 breast cancer cells treated by Prunus armeniaca. Expression levels of the genes were evaluated by $\mathrm{qPCR}$ and compared to untreat and control cells by $\triangle \Delta \mathrm{Ct}$ method. ${ }^{* *}$. Shows significant at the 0.001 level. Error bars show $\pm \mathrm{SE}$

cancer cell line were examined. The mRNA expression profiles of each of these genes were different depending on the treatment type and treatment time passed [23].

One major limitation of this study was limited number and variant of cancer cells that might not fully substantiate the accuracy of the results.

\section{Conclusion}

Novel naturals for high throughput analysis of the expression profile of breast cancer, under a variety of experimental and treatment conditions, are becoming widespread. The relations underlying Bax and c-FLIP genes expression under treatment with Prunus armeniaca extract may be helpful in the prevention and cure of breast cancer cells. However, further studies are required to thoroughly characterize the relationship between apoptosis and Prunus armeniaca extract of breast cancer cells.

\section{Abbreviations}

Bax: BCl-2-associated X; C-FLIP: Cellular FLICE-inhibitory protein; DISC: Deathinducing signaling complex; FBS: Fetal Bovine Serum; MTT: 3-(4,5-dimethylthiazol2-yl)-2,5- dimethyltetrazolium bromide; NTC: No template controls

\section{Acknowledgements}

The authors would like to thank all the staff members of the Cellular and Molecular Research Center of Shahrekord University of Medical Sciences in Iran for their sincere supports.

\section{Funding}

Not applicable.

\section{Availability of data and materials}

All data generated or analyzed during this study are included in this published article.

\section{Authors' contributions}

$\mathrm{EM}, \mathrm{MA}, \mathrm{NH}$ and YEM designed and performed experiments; MDS and MK collected and analyzed the data. HK and MN provided help. AA supervised the study and wrote the manuscript. All the authors read and approved the final manuscript.
Ethics approval and consent to participate

The study protocol was approved by the ethics committee of Cellular and Molecular Research Center of Shahrekord University of Medical Sciences.

\section{Consent for publication}

Not applicable.

Competing interests

The authors declare that they have no competing interests.

\section{Publisher's Note}

Springer Nature remains neutral with regard to jurisdictional claims in published maps and institutional affiliations.

\section{Author details}

${ }^{1}$ Young Researchers and Elite Club, Shahrekord Branch, Islamic Azad University, Shahrekord, Iran. ${ }^{2}$ Department of Immunology, Basic Health Sciences Institute, Shahrekord University of Medical Sciences, Shahrekord, Iran. ${ }^{3}$ Department of Biology, Tehran Medical Branch, Islamic Azad University, Tehran, Iran. ${ }^{4}$ Clinical Biochemistry Research Center, Shahrekord University of Medical Science, Shahrekord, Iran. ${ }^{5}$ Department of Genetics, Faculty of Basic Sciences, Shahrekord University, Shahrekord, Iran. ${ }^{6}$ Medical Microbiology, Student Research Committee, Shahrekord University of Medical Sciences, Shahrekord, Iran. ${ }^{7}$ Students Research Committee, Babol University of Medical Science, Babol, Iran. ${ }^{8}$ Department of Medicine, Najafabad Branch, Islamic Azad University, Najafabad, Iran. ${ }^{9}$ Young Researchers and Elite Club, Najafabad Branch, Islamic Azad University, Najafabad, Iran.

Received: 10 March 2019 Accepted: 26 March 2019

Published online: 02 April 2019

\section{References}

1. Siegel RL, Miller KD, Jemal A. Cancer statistics, 2018. CA Cancer J Clin. 2018; 68:7-30.

2. Elmore S. Apoptosis: a review of programmed cell death. Toxicol Pathol. 2007:35:495-516.

3. Portt L, Norman G, Clapp C, Greenwood M, Greenwood MT. Anti-apoptosis and cell survival: a review. Biochim Biophys Acta Mol Cell Res. 2011;1813: 238-59.

4. Scaffidi C, Schmitz I, Krammer PH, Peter ME. The role of C-FLIP in modulation of CD95-induced apoptosis. J Biol Chem. 1999;274:1541-8.

5. Iyer AKV, Azad N, Talbot S, Stehlik C, Lu B, Wang L, et al. Antioxidant C-FLIP inhibits Fas ligand-induced NF- B activation in a phosphatidylinositol 3kinase/Akt-dependent manner. J Immunol. 2011;187:3256-66.

6. Day TW, Sinn AL, Huang S, Pollok KE, Sandusky GE, Safa AR. C-FLIP gene silencing eliminates tumor cells in breast cancer xenografts without affecting stromal cells. Anticancer Res. 2009;29:3883-6. 
7. Pluta P, Smolewski P, Pluta A, Cebula-Obrzut B, Wierzbowska A, Nejc D, et al. Significance of Bax expression in breast Cancer patients. Polish J Surg. 2011; 83:549-53.

8. Suzuki K, Kazui T, Yoshida M, Uno T, Kobayashi T, Kimura T, et al. Druq-induced apoptosis and p53, BCL-2 and BAX expression in breast cancer tissues in vivo and in fibroblast cells in vitro. Jpn J Clin Oncol. 1999;29:323-31.

9. Kholoussi NM, El-Nabi SEH, Esmaiel NN, Abd El-Bary NM, El-Kased AF. Evaluation of Bax and Bak gene mutations and expression in breast cancer. Biomed Res Int Hindawi. 2014;2014:249372.

10. Yiğit D, Yiğit N, Mavi A. Antioxidant and antimicrobial activities of bitter and sweet apricot (Prunus armeniaca L.) kernels. Brazilian J Med Biol Res. 2009; 42:346-52.

11. Gomaa EZ. In vitro antioxidant, antimicrobial, and antitumor activities of bitter almond and sweet apricot (Prunus armeniaca L.) kernels. Food Sci Biotechnol. 2013:22:455-63 The Korean Society of Food Science and Technology.

12. Livak KJ, Schmittgen TD. Analysis of relative gene expression data using real-time quantitative PCR and the 2(-Delta Delta C(T)) method. Methods. 2001:25:402-8

13. Yu LL, Yu HG, Yu JP, Luo HS, Xu XM, Li JH. Nuclear factor-kappaB p65 (RelA) transcription factor is constitutively activated in human colorectal carcinoma tissue. World J Gastroenterol. 2004;10:3255-60 Baishideng Publishing Group Inc.

14. Kobayashi T, Sawa H, Morikawa J, Zhang W, Shiku H. Bax induction activates apoptotic cascade via mitochondrial cytochrome $\mathrm{c}$ release and Bax overexpression enhances apoptosis induced by chemotherapeutic agents in DLD-1 colon cancer cells. Jpn J Cancer Res. 2000;91:1264-8.

15. Hawkins N, Lees J, Hargrave R, O'Connor T, Meagher A, Ward R. Pathological and genetic correlates of apoptosis in the progression of colorectal neoplasia. Tumour Biol. 1997;18:146-56.

16. Yamaguchi H, Bhalla K, Wang H-G. Bax plays a pivotal role in thapsigargininduced apoptosis of human colon cancer HCT116 cells by controlling Smac/diablo and Omi/HtrA2 release from mitochondria. Cancer Res. 2003; 63:1483-9.

17. Zhou XD, Yu JP, Liu J, Luo HS, Chen HX, Yu HG. Overexpression of cellular FLICE-inhibitory protein (FLIP) in gastric adenocarcinoma. Clin Sci. 2004;106: 397-405.

18. Buchholz TA, Garg AK, Chakravarti N, Aggarwal BB, Esteva FJ, Kuerer HM, et al. The nuclear transcription factor $\mathrm{B} / \mathrm{bcl}-2$ pathway correlates with pathologic complete response to doxorubicin-based neoadjuvant chemotherapy in human breast Cancer. Clin Cancer Res. 2005;11:8398-402.

19. Lee KH, Im SA, Oh DY, Lee SH, Chie EK, Han W, et al. Prognostic significance of bcl-2 expression in stage III breast cancer patients who had received doxorubicin and cyclophosphamide followed by paclitaxel as adjuvant chemotherapy. BMC Cancer. 2007;7:63.

20. Levitsky DO, Dembitsky VM. Anti-breast Cancer agents derived from plants. Nat Products Bioprospect. 2014:5:1 Springer.

21. Shareef M, Ashraf MA, Sarfraz M. Natural cures for breast cancer treatment Saudi Pharm J. 2016;24:233-40 SPJ Off Publ Saudi Pharm Soc Elsevier.

22. Kordezangeneh M, Irani S, Mirfakhraie R, Esfandyari-Manesh M, Atyabi F, Dinarvand R. Regulation of BAX/BCL2 gene expression in breast cancer cells by docetaxel-loaded human serum albumin nanoparticles. Med Oncol. 2015;32:208

23. Thomadaki H, Scorilas A. Breast Cancer cells response to the antineoplastic agents cisplatin, carboplatin, and doxorubicin at the mRNA expression levels of distinct apoptosis-related genes, including the new member, BCL2L12. Ann N Y Acad Sci. 2007;1095:35-44.

Ready to submit your research? Choose BMC and benefit from:

- fast, convenient online submission

- thorough peer review by experienced researchers in your field

- rapid publication on acceptance

- support for research data, including large and complex data types

- gold Open Access which fosters wider collaboration and increased citations

- maximum visibility for your research: over $100 \mathrm{M}$ website views per year

At BMC, research is always in progress.

Learn more biomedcentral.com/submissions 